\title{
Polyethylene glycol in water: A simple, efficient and green protocol for the synthesis of quinoxalines
}

\author{
HEMANT V CHAVAN, LAXMAN K ADSUL and BABASAHEB P BANDGAR* \\ Medicinal Chemistry Research Laboratory, School of Chemical Sciences, Solapur University, \\ Solapur 413 255, (MS) India \\ e-mail: bandgar_bp@yahoo.com
}

MS received 7 October 2010; accepted 28 February 2011

\begin{abstract}
A variety of biologically important quinoxaline derivatives has been efficiently synthesized in excellent yields under extremely mild conditions using PEG-600 and water. This inexpensive, non-toxic, ecofriendly and readily available system efficiently condensed several aromatic as well as aliphatic 1,2-diketones with aromatic and aliphatic 1,2-diamines to afford the products in excellent yield. Polyethylene glycol (PEG) can be recovered and recycled.
\end{abstract}

Keywords. Polyethylene glycol (PEG); water; 1,2-dicarbonyls; 1,2-diamines; recyclability; quinoxalines.

\section{Introduction}

Quinoxaline derivatives are important class of nitrogencontaining heterocycles, having interesting therapeutic properties such as antiviral, antibacterial, antibiotic, antiinflammatory and kinase inhibition. ${ }^{1}$ They have also been evaluated as anticancer, antimycobacterial, and anthelmintic agents. ${ }^{2}$ Besides this, they are potential building blocks for the synthesis of anion receptors, ${ }^{3}$ cavitands, ${ }^{4}$ dehydroannulenes, ${ }^{5}$ organic semiconductors, ${ }^{6}$ and dyes. ${ }^{7}$ Molecules like dipyrido[3,2-a:2',3'-c] phenazine (dppz), ${ }^{8}$ dipyrido[3,2-f:2',3'-h]quinoxaline $(\mathrm{dpq})^{9}$ and tetrapyrido[3,2-a:2',3'-c:3",2"'-h:2"',3"'j]phenazine $(\mathrm{tpphz})^{10}$ derivatives exhibit interesting properties, such as bidentate coordination ability, rigidity, $\pi$-accepting character and planar highly conjugated aromatic structure (figure 1). All these interesting properties and nitrogen sites enable them to act as therapeutic agents that are capable of binding and cleaving DNA under the physiological condition. ${ }^{11}$ In addition, organometallic complexes of these ligands show interesting optical, electrochemical and electroluminescent properties. ${ }^{12}$

A number of methods have been developed for the synthesis of substituted quinoxaline derivatives and the most common method is the condensation of an aryl 1,2-diamine with 1,2-dicarbonyl compounds

*For correspondence in refluxing ethanol or acetic acid. ${ }^{13}$ Apart from this, other methods such as solid phase synthesis, ${ }^{14}$ oxidative cyclisation of $\alpha$-hydroxy ketones with 1,2-diamines, ${ }^{15}$ cyclisation-oxidation of phenacyl bromides with 1,2 -diamines by $\mathrm{HClO}_{4}-\mathrm{SiO}_{2},{ }^{16}$ cyclisation of $o$-phenylenediamine with propiophenone by using $\mathrm{KOH},{ }^{17}$ and oxidative coupling of epoxides with ene1,2-diamines ${ }^{18}$ have also been reported. Nevertheless, most of the methods suffer from several drawbacks such as critical product isolation, expensive metal catalyst, harsh reaction conditions, and use of strong oxidizing agents, long reaction time and low yields. Therefore, the development of simple, more efficient and environmentally benign method is useful in generating organic compounds in drug discovery process.

An increase in regulatory restrictions on the use, manufacture and disposal of organic solvents has focused attention on the development of non-hazardous alternatives for the sustainable development of chemical enterprise. Liquid polymers have been used as green reaction media with unique properties such as thermal stability, commercial availability, non-volatility, immiscibility with organic solvents and recyclability. Recently, polyethylene glycol (PEG) and its aqueous solutions represent interesting solvent systems for solvent replacement, and may stand comparison to other currently favoured systems such as ionic liquids, supercritical carbon dioxide, and micellar systems. ${ }^{19}$ PEGs are selected instead of other polymers because they are inexpensive, biodegradable, non-halogenated and having low toxicity. 
<smiles>c1cnc2c(c1)c1cccnc1c1nccnc21</smiles>

dpq<smiles>c1cnc2c3nc4cccnc4c4ncccc4c-3nc2c1</smiles>

dppz<smiles>c1cnc2c(c1)c1nc3c4ncccc4c4nccnc4c3nc1c1cccnc12</smiles>

tpphz

Figure 1. Representatives of quinoxaline ring containing compounds.<smiles>Nc1ccc(CC2CC3CCC2C3)cc1N</smiles>

Scheme 1. Synthesis of quinoxaline.

As a part of ongoing program on the development of novel methods in organic synthesis, ${ }^{20}$ we report here a simple, efficient and green protocol for the synthesis of quinoxalines. In this protocol, 1,2-diketone $\mathbf{1}$ and 1,2-diamine 2 in PEG- $\mathrm{H}_{2} \mathrm{O}$ after stirring at room temperature for specified time resulted in the formation of product 3a in $98 \%$ yield (scheme 1).

\section{Experimental}

\subsection{General procedure for the synthesis of quinoxalines}

A mixture containing 1,2-dicarbonyl compound $\mathbf{1}$ (1 mmol) and 1,2-diamine 2 (1 mmol) in PEG-600- $\mathrm{H}_{2} \mathrm{O}$ $(1: 1,5 \mathrm{ml})$ was stirred at room temperature for the specified time. After completion of the reaction (TLC), water $(10 \mathrm{ml})$ was added to the reaction mixture. Precipitate obtained was filtered, washed with water and dried to obtain quinoxaline $\mathbf{3}$ in almost pure form. All the products were characterized by IR, ${ }^{1} \mathrm{H} \mathrm{NMR},{ }^{13} \mathrm{C}$ NMR, and Mass Spectroscopy.

\subsection{Spectral data of some representative compounds}

2.2a 2,3-Diphenyl-quinoxaline (3a): White solid; yield 98\%; mp $126^{\circ} \mathrm{C}$; IR (KBr): 3056, 1964, 1577 , 1556, 1540, $1495 \mathrm{~cm}^{-1}$; ${ }^{1} \mathrm{H}$ NMR $(400 \mathrm{MHz}$, DMSO$\left.\mathrm{d}^{6}\right): \delta 7.35(\mathrm{~m}, 6 \mathrm{H}), 7.50(\mathrm{~m}, 4 \mathrm{H}), 7.90(\mathrm{dd}, J=8,2 \mathrm{~Hz}$, $2 \mathrm{H}), 8.20(\mathrm{~d}, J=8,2 \mathrm{~Hz}, 2 \mathrm{H}) ;{ }^{13} \mathrm{C} \mathrm{NMR}(100 \mathrm{MHz}$, $\left.\mathrm{CDCl}_{3}\right): \delta$ 128.2, 128.8, 129.2, 129.8, 129.9, 139.1, 141.2, 153.5; MS (ESI): $m / z 283(\mathrm{M}+\mathrm{H})^{+}$.
$2.2 \mathrm{~b}$ 2,3-Bis-(4-fluoro-phenyl)-quinoxaline (3b): Colourless solid; yield 96\%; mp $104^{\circ} \mathrm{C}$; IR (KBr): 3074, 3061, 1664, 1599, $1512 \mathrm{~cm}^{-1} ;{ }^{1} \mathrm{H}$ NMR $(400 \mathrm{MHz}$, DMSO-d $\left.^{6}\right): \delta 7.24(\mathrm{~m}, 4 \mathrm{H}), 7.52(\mathrm{~m}, 2 \mathrm{H}), 7.90(\mathrm{~m}$, 2H), 8.05 (m, 2H), 8.20 (m, 2H); ${ }^{13} \mathrm{C} \mathrm{NMR} \mathrm{(100} \mathrm{MHz,}$ $\left.\mathrm{CDCl}_{3}\right): \delta 128.4,129.2,130.1,132.6,133.4,144.2$, 155.1; MS (ESI): $m / z 319(\mathrm{M}+\mathrm{H})^{+}$.

2.2c Dipyrido[3,2-a:2',3'-c]phenazine (dppz) (3c): Light brown; yield 95\%; mp $246^{\circ} \mathrm{C}$; IR (KBr): 3079, 3052, 3025, 1590, 1492, $1081 \mathrm{~cm}^{-1} ;{ }^{1} \mathrm{H}$ NMR $\left(400 \mathrm{MHz}, \mathrm{DMSO}-\mathrm{d}^{6}\right): \delta=9.68(\mathrm{dd}, J=8.2,1.3 \mathrm{~Hz}$, $2 \mathrm{H}) ; 7.95(\mathrm{dd}, J=8.2,5.4 \mathrm{~Hz}, 2 \mathrm{H}) ; 8.30(\mathrm{dd}, J=5.4$, $1.3 \mathrm{~Hz}, 2 \mathrm{H}) ; 8.42(\mathrm{~d}, J=8.0 \mathrm{~Hz} ; 2 \mathrm{H}) ; 8.14(\mathrm{~d}, J=$ $8.0 \mathrm{~Hz}, 2 \mathrm{H}) ;{ }^{13} \mathrm{C} \mathrm{NMR}\left(100 \mathrm{MHz}, \mathrm{CDCl}_{3}\right): \delta 125.8$, 129.6, 130.2, 130.8, 131.1, 138.4, 144.6, 147.8, 153.2; MS (ESI): $m / z 283(\mathrm{M}+\mathrm{H})^{+}$.

2.2d Dibenzo[a,c]phenazine (3d): Yellow solid; yield $97 \%$; mp $218^{\circ} \mathrm{C}$; IR (KBr): 3059, 3032, 1604, $1500 \mathrm{~cm}^{-1} ;{ }^{1} \mathrm{H}$ NMR (400 MHz, DMSO-d $\left.{ }^{6}\right): \delta=7.82$ $(\mathrm{m}, 2 \mathrm{H}), 7.90(\mathrm{~m}, 2 \mathrm{H}), 8.00(\mathrm{~m}, 2 \mathrm{H}), 8.35(\mathrm{~m}, 2 \mathrm{H})$, $8.80(\mathrm{~d}, J=8 \mathrm{~Hz}, 2 \mathrm{H}), 9.28(\mathrm{~d}, J=8 \mathrm{~Hz}, 2 \mathrm{H}) ;{ }^{13} \mathrm{C}$ NMR (100 MHz, $\left.\mathrm{CDCl}_{3}\right): \delta$ 126.2, 127.1, 127.6, 128.1, 129.8, 130.7, 132.4, 135.9, 142.6, 151.2; MS (ESI): $m / z 281(\mathrm{M}+\mathrm{H})^{+}$.

2.2e 2,3-Difuran-2-yl-quinoxaline (3e): Pale brown solid; yield 97\%; mp $130^{\circ} \mathrm{C}$; IR (KBr): 3107, 3061, 1572, 1529, $1400 \mathrm{~cm}^{-1}$; ${ }^{1} \mathrm{H}$ NMR (400 MHz, DMSO$\left.\mathrm{d}^{6}\right): \delta=6.72(\mathrm{~s}, 4 \mathrm{H}), 7.90(\mathrm{~m}, 4 \mathrm{H}), 8.10(\mathrm{~m}, 2 \mathrm{H}) ;{ }^{13} \mathrm{C}$ NMR $\left(100 \mathrm{MHz}, \mathrm{CDCl}_{3}\right): \delta 120.1,129.8,132.2,144.6$, 146.5, 148.4, 156.9; MS (ESI): $m / z 263(\mathrm{M}+\mathrm{H})^{+}$.

2.2f 2,3-Diphenylpyrido[2,3-b]pyrazine (3g): Yellow solid, yield $94 \%$; mp $257^{\circ} \mathrm{C}$; IR (KBr): 1588,1545 , 1430, 1382, $1328 \mathrm{~cm}^{-1} ;{ }^{1} \mathrm{H}$ NMR (400 MHz, DMSO$\left.\mathrm{d}^{6}\right): \delta=7.31-7.41(\mathrm{~m}, 6 \mathrm{H}), 7.56(\mathrm{~d}, J=7.8 \mathrm{~Hz}, 2 \mathrm{H})$, $7.64(\mathrm{~d}, J=7.8 \mathrm{~Hz}, 2 \mathrm{H}), 7.74-7.76(\mathrm{dd}, J=8.4,4.1 \mathrm{~Hz}$, 1H), 8.55-8.57 (d, $J=8.2 \mathrm{~Hz}, 1 \mathrm{H}), 9.19$ (d, $J=4.2 \mathrm{~Hz}$, 
<smiles>O=C1C(=O)c2cccnc2-c2ncccc21</smiles>

4<smiles>Nc1c(N)c2cccnc2c2ncccc12</smiles>

5

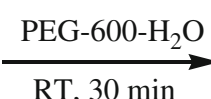<smiles>c1cnc2c(c1)-c1nc3cccnc3c3nc4c-2ncccc-4c13</smiles>

6

Scheme 2. Synthesis of tetrapyrido[3,2-a:2',3'-c:3",2"-h:2"',3"'-j]phenazine (tpphz).

$1 \mathrm{H}) ;{ }^{13} \mathrm{C}$ NMR $\left(100 \mathrm{MHz}, \mathrm{CDCl}_{3}\right): \delta 125.2,128.2$, 128.5, 129.4, 129.6, 129.8, 130.3, 136.2, 138.0, 138.5, 149.4, 153.6, 155.0, 156.6; MS (ESI): $m / z 283\left(\mathrm{M}^{+}\right)$.

$2.2 \mathrm{~g}$ 5,6-Diphenyl-2,3-dihydro-pyrazine (3l): White solid; yield 94\%; $\mathrm{mp} 156^{\circ} \mathrm{C}$; IR (KBr): 3081, 2943 , 2832, 1964, 1896, 1610, $1572 \mathrm{~cm}^{-1} ;{ }^{1} \mathrm{H}$ NMR (DMSO$\left.\mathrm{d}^{6}\right): \delta=3.60(\mathrm{~s}, 4 \mathrm{H}), 7.30(\mathrm{~m}, 10 \mathrm{H}) ;{ }^{13} \mathrm{C}$ NMR $\left(100 \mathrm{MHz}, \mathrm{CDCl}_{3}\right): \delta 52.4,128.2,129.4,130.8,136.8$, 161.6; MS (ESI): $m / z 235(\mathrm{M}+\mathrm{H})^{+}$.

$2.2 \mathrm{~h}$ 1,2,3,4-Tetrahydro-phenazine (3m): white solid, yield $90 \%, \mathrm{mp} 178^{\circ} \mathrm{C}$, IR (KBr): 1459, 1423, 1384, 1330, 1291, $1238 \mathrm{~cm}^{-1} ;{ }^{1} \mathrm{H}$ NMR $\left(400 \mathrm{MHz}, \mathrm{CDCl}_{3}\right) \delta$ $=2.04(\mathrm{~m}, 4 \mathrm{H}), 3.16(\mathrm{~m}, 4 \mathrm{H}), 7.65(\mathrm{~m}, 2 \mathrm{H}), 7.97(\mathrm{~m}$, $2 \mathrm{H}) ;{ }^{13} \mathrm{C} \mathrm{NMR}\left(100 \mathrm{MHz}, \mathrm{CDCl}_{3}\right): \delta 22.8,33.2,128.3$, 128.9, 141.2, 154.1; MS (ESI): $m / z 184\left(\mathrm{M}^{+}\right)$.

$2.2 \mathrm{i}$ 2,3,2',3'-Tetraphenyl-[6,6'] biquinoxalinyl (3q): Yellow solid; yield $89 \%$; $\mathrm{mp}>295^{\circ} \mathrm{C}$; IR (KBr): 3084, 3055, 3032, 1612, $1599 \mathrm{~cm}^{-1} ;{ }^{1} \mathrm{H}$ NMR (DMSO-d ${ }^{6}$ ): $\delta=7.35(\mathrm{~m}, 12 \mathrm{H}), 7.55(\mathrm{~d}, J=8.1 \mathrm{~Hz}, 8 \mathrm{H}), 8.23(\mathrm{~d}, J$ $=8.5 \mathrm{~Hz}, 2 \mathrm{H}), 8.32(\mathrm{~d}, J=8.5 \mathrm{~Hz}, 2 \mathrm{H}), 8.60(\mathrm{~s}, 2 \mathrm{H})$; ${ }^{13} \mathrm{C}$ NMR $\left(100 \mathrm{MHz}, \mathrm{CDCl}_{3}\right): \delta 155.8,154.2,142.1$, 141.7, 141.3, 140.0, 131.1, 130.8, 130.5, 130.1, 129.0, 128.3; MS (ESI): $m / z 563(\mathrm{M}+\mathrm{H})^{+}$.

Table 1. Effect of the PEG-600 to $\mathrm{H}_{2} \mathrm{O}$ volume ratio on quinoxaline synthesis.

\begin{tabular}{lcccc}
\hline Entry & PEG $(\mathrm{ml})$ & $\mathrm{H}_{2} \mathrm{O}(\mathrm{ml})$ & Time $(\mathrm{min} / \mathrm{hr})$ & Yield $(\%)^{\mathrm{a}}$ \\
\hline 1 & 5 & 0 & $20 \mathrm{~min}$ & 83 \\
2 & 4 & 1 & $15 \mathrm{~min}$ & 89 \\
3 & 2.5 & 2.5 & $3 \mathrm{~min}$ & 98 \\
4 & 1 & 4 & $1.5 \mathrm{hr}$ & 82 \\
5 & 0 & 5 & $6 \mathrm{hr}$ & 59 \\
\hline
\end{tabular}

Reaction conditions: Benzil ( $1 \mathrm{mmol}), o$-phenylenediamine (1 mmol), PEG- $\mathrm{H}_{2} \mathrm{O}$, RT

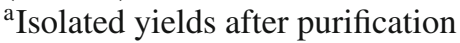

2.2j Tetrapyrido[3,2-a:2',3'-c:3",2"-h:2"',3"'-j]phenazine (tpphz) (scheme 2, compound 6): Yellow solid; Yield 73\%; $\mathrm{mp}>295^{\circ} \mathrm{C}$; IR (KBr): 3082, 3061, 3026, 1595, 1496, $1082 \mathrm{~cm}^{-1} ;{ }^{1} \mathrm{H}$ NMR $\left(400 \mathrm{MHz}, \mathrm{CDCl}_{3}\right)$ : $\delta=7.92(\mathrm{dd}, J=8.4,5.2 \mathrm{~Hz}, 4 \mathrm{H}) ; 9.40(\mathrm{dd}, J=5.2$, $1.7 \mathrm{~Hz}, 4 \mathrm{H}) ; 9.87(\mathrm{dd}, J=8.4,1.7 \mathrm{~Hz}, 4 \mathrm{H}) ;{ }^{13} \mathrm{C} \mathrm{NMR}$ $\left(100 \mathrm{MHz}, \mathrm{CDCl}_{3}\right): \delta 125.2,130.6,131.1,138.5$ 146.8, 155.4; MS (ESI): $m / z 385(\mathrm{M}+\mathrm{H})^{+}$

\section{Results and discussion}

In the beginning, a reaction of benzil and $o$ phenylenediamine in water was carried out at room temperature, which resulted in the formation of a condensation product 3a after 6 hours (59\%). With similar substrates, reaction was carried out in PEG-600 afforded the title compound 3a in $20 \mathrm{~min}$ ( $83 \%$ yield). Inspired by these results, we introduced $\mathrm{PEG}-\mathrm{H}_{2} \mathrm{O}$ as a solvent system and found that the reaction rate was significantly improved. By changing proportion of PEG$\mathrm{H}_{2} \mathrm{O}$, dramatic effect on the conversion rate of quinoxaline has been observed (table 1). As shown in table 1, when pure PEG was used as a solvent, the reaction was completed in $20 \mathrm{~min}$. However, addition of water to PEG increased the rate of the reaction as well as yield of the product (table 1, entries 2, 3). When the proportion of $\mathrm{PEG}-\mathrm{H}_{2} \mathrm{O}$ was $1: 1$, the highest reaction rate was observed (table 1, entry 3 ). On the other hand,

Table 2. Optimisation of reaction conditions using different $\mathrm{PEG}-\mathrm{H}_{2} \mathrm{O}$ systems.

\begin{tabular}{lccc}
\hline Entry & Solvent $^{\mathrm{a}}$ & Time (min) & Yield (\%) \\
\hline 1 & PEG-200- $\mathrm{H}_{2} \mathrm{O}$ & 12 & 87 \\
2 & PEG-300- $\mathrm{H}_{2} \mathrm{O}$ & 8 & 94 \\
3 & PEG-400- $\mathrm{H}_{2} \mathrm{O}$ & 5 & 97 \\
4 & PEG-600- $\mathrm{H}_{2} \mathrm{O}$ & 3 & 98 \\
5 & PEG-800- $\mathrm{H}_{2} \mathrm{O}$ & 5 & 96
\end{tabular}

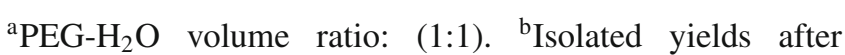
purification 
Table 3. Synthesis of quinoxaline using different aromatic, heterocyclic and aliphatic 1,2-diketones.

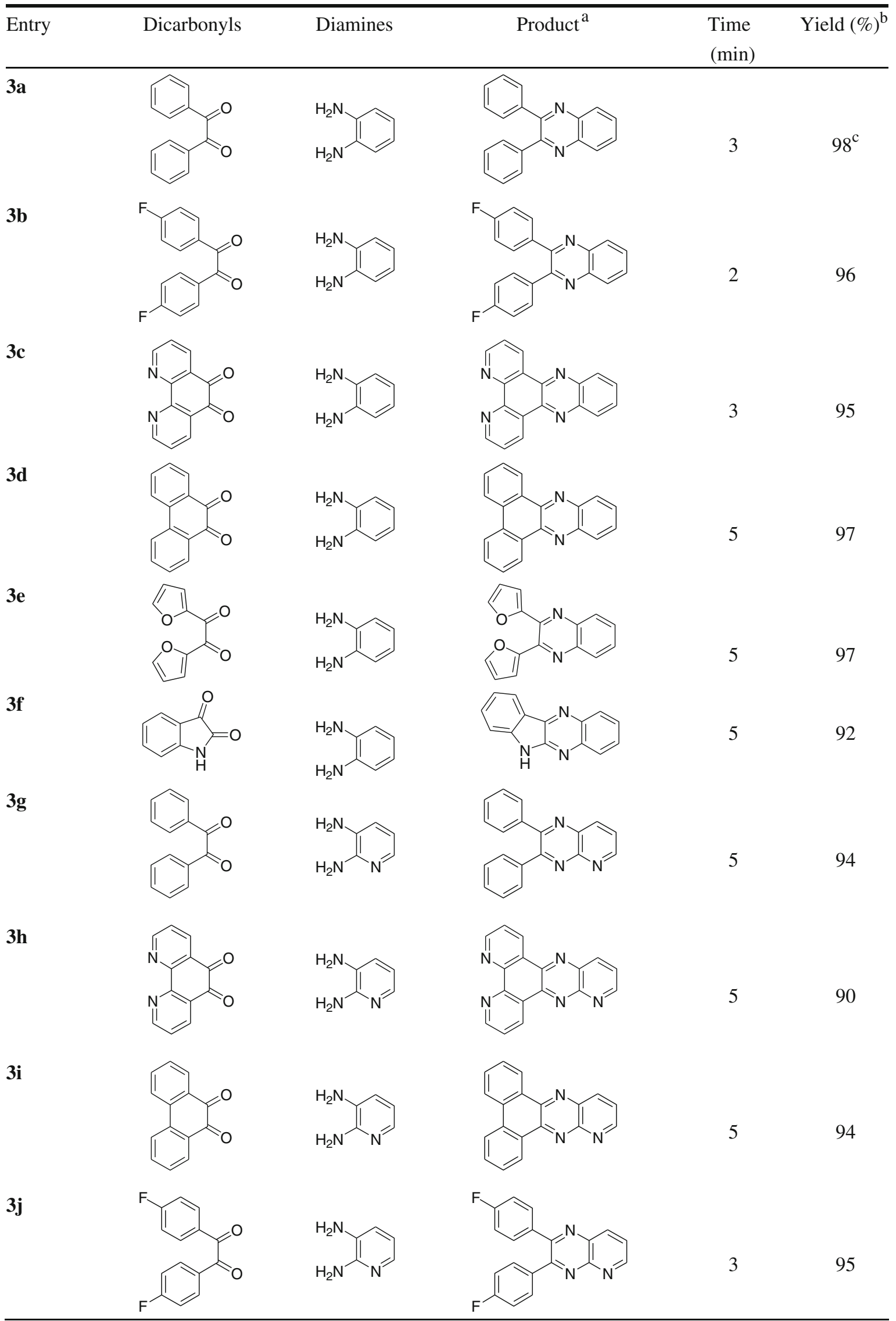


Table 3. (continued).

\begin{tabular}{|c|c|c|c|c|c|}
\hline Entry & Dicarbonyls & Diamines & Product & $\begin{array}{l}\text { Time } \\
(\min )\end{array}$ & Yield $(\%)^{\mathrm{b}}$ \\
\hline $3 \mathbf{k}$ & & $\mathrm{H}_{2}$ & & 5 & 95 \\
\hline 31 & & & & 2 & 94 \\
\hline $3 m$ & & & & & 90 \\
\hline $3 n$ & & & & 2 & 92 \\
\hline 30 & & & & 5 & 89 \\
\hline $3 p$ & & & & 5 & 85 \\
\hline $3 q$ & & & & 5 & 89 \\
\hline
\end{tabular}

Reaction conditions: PEG-600- $\mathrm{H}_{2} \mathrm{O}$. ${ }^{\mathrm{a}}$ All products were characterised by $\mathrm{IR},{ }^{1} \mathrm{H} \mathrm{NMR},{ }^{13} \mathrm{C}$ NMR and MS.

${ }^{\mathrm{b}}$ Isolated yields after purification. ${ }^{\mathrm{c}} \mathrm{PEG}$ was recovered and reused for three consecutive runs

further addition of water resulted in decrease reaction rate due to decreased solubility of substrates in PEG- $\mathrm{H}_{2} \mathrm{O}$. In summary, to obtain high reactivity within a short period of time, an optimum volume ratio of PEG to $\mathrm{H}_{2} \mathrm{O}$ was necessary, for example, 1:1 during quinoxaline synthesis.

We have also studied the effect of PEG with different molecular weights on the rate of quinoxaline formation. The rate of conversion increased continuously with the increase in the molecular weight of PEG from PEG-200 to PEG-600 and decreased when the molecular weight was over 600 . This could be attributed to the lower viscosity and better hydrophilic character but the low solubility of the substrates in PEG with low molecular weight. When PEGs with molecular weight over 600 were used, decreased rate of reaction was observed due to higher viscosity of the reaction medium. As a result of the above studied parameters, PEG-600- $\mathrm{H}_{2} \mathrm{O}(1: 1)$ system, found to be effective for the synthesis of quinoxalines at room 
temperature with excellent yield within a short reaction time (table 2). Furthermore, PEG-600 may be recovered in almost pure form by removal of water under diminished pressure and recycled. ${ }^{16}$ There was no decrease in the yield even after three subsequent experiments with recovered and reused PEG-600.

In an optimized reaction condition, 1,2-diketone $(1 \mathrm{mmol})$ and 1,2-diamine $(1 \mathrm{mmol})$ in PEG-600- $\mathrm{H}_{2} \mathrm{O}$ $(5 \mathrm{~mL})$ were mixed and stirred at room temperature for 2-5 min. After completion of the reaction (TLC), a simple work-up afforded the product in excellent yield. Present methodology is very simple, efficient, clean and without any side-products. In order to demonstrate the versatility of the PEG-600- $\mathrm{H}_{2} \mathrm{O}$ promoted synthesis of quinoxalines, a series of 1,2-diketones and 1,2diamines were subjected to condensation (table 3 ). All these reactions showed rapid formation of quinoxalines at room temperature with high efficiency. However, the variations in the yields were very small and both aromatic and aliphatic 1,2-diketones gave the condensed products in excellent yields with different 1,2-diamines. The products were characterized by ${ }^{1} \mathrm{H}$ NMR, IR and Mass spectroscopic data. In addition, this methodology is also useful for the synthesis of sterically hindered quinoxaline such as tetrapyrido[3,2a:2',3'-c:3",2"-h:2"',3"'-j]phenazine (tpphz) 6 (73\% yield) by condensing $[1,10]$ phenanthroline-5,6-dione 4 with $[1,10]$ phenanthroline-5,6-diamine 5 in PEG-600$\mathrm{H}_{2} \mathrm{O}$ (scheme 2). This new molecule may have biological potential, synthetic and technological importance and they may also provide new prototypes for DNA interaction.

\section{Conclusion}

In conclusion, we have developed a novel, efficient and eco-friendly method for the synthesis of quinoxalines from various 1,2-diketones and 1,2-diamines using PEG- $\mathrm{H}_{2} \mathrm{O}$ as a new reaction medium. This medium rendered this procedure attractive and environmentally benign. In addition to its efficiency and simplicity, this method provided high yields of biologically potent quinoxalines in short reaction time.

\section{Acknowledgement}

HVC thanks Council of Scientific and Industrial Research (CSIR), New Delhi, India, for the award of Junior Research Fellowship.

\section{References}

1. (a) He W, Meyers M R, Hanney B, Sapada A, Blider G, Galzeinski H, Amin D, Needle S, Page K, Jayyosi Z and Perrone H 2004 Bioorg. Med. Chem. Lett. 13 3097; (b) Kim Y B, Kim Y H, Park J Y and Kim S K 2004 Bioorg. Med. Chem. Lett. 14 541; (c) Gazit A, App H, McMohan G, Chen J, Levitzki A and Bohmer F 1996 J. Med. Chem. 39 2170

2. (a) Jaso A, Zarranz B, Aldana I and Monge A $2005 \mathrm{~J}$. Med. Chem. 48 2019; (b) Seitz L E, Suling W J and Reynolds R C 2002 J. Med. Chem. 45 5604; (c) Sakata G, Makino K, and Kuraswa Y 1988 Heterocycles 27 2481

3. Jonathan L S, Hiromitsu M, Toshihisa M, Vincent M L and Hiroyuki F J 2002 Chem. Commun. 8862

4. (a) Jonathan L S, Hiromitsu M, Toshihisa M, Vincent M L and Hiroyuki F 2002 J. Am. Chem. Soc. 124 13474; (b) Peter P C, Gang Z, Grace A M, Carlos H and Linda M G T 2004 Org. Lett. 633

5. Sascha O and Rudiger F 2004 Synlett. 91509

6. (a) Dailey S, Feast J W, Peace R J, Saga R C, Till S and Wood E L 2001 J. Mater. Chem. 11 2238; (b) O'Brien D, Weaver M S, Lidzey D G and Bradley D C 1996 Appl. Phys. Lett. 69881

7. Brock E D, Lewis D M, Yousaf T I and Harper H H 1999 (The Procter and Gamble Company, USA) WO 9951688

8. Dickeson J E and Summers L A 1970 Aust. J. Chem. 23 1023

9. Amouyal E, Homsi A, Chambron J-C and Sauvage J-P 1990 Dalton Trans. 61841

10. Bolger J, Gourdon A, Ishow E and Launay J-P 1995 Chem. Commun. 171799

11. (a) Gupta N, Grover N, Neyhart G A, Liang W, Singh $\mathrm{P}$ and Thorp H H 1992 Angew. Chem. 31 1048; (b) Chetna P R, Rao R, Roy M and Patra A K 2009 Inorg. Chem. Acta 362 4692; (c) Miranda F S, Signori A M, Vicente J, Souza B, Priebe J P, Szpoganicz B, Goncalves N S and Neves A 2008 Tetrahedron 64 5410

12. (a) Zhang L and Li B J 2009 Lumin. 129 1304; (b) Bolger J, Gourdon A, Ishow E and Launay J-P 1996 Inorg. Chem. 35 2937; (c) Thomas K R, Marappan V, Jiann T L, Chang-Hao C and Yu-ai T 2005 Chem. Mater. 171860

13. (a) VOGEL's Textbook of practical organic chemistry, 5th ed.; 1989, p. 1190; (b) Brown D J 2004 In the chemistry of heterocyclic compounds, quinoxalines supplements II (eds) E C Taylor and P Wipf (New Jersey; John Wiley and sons); (c) Yadav J S, Subba Reddy B V, Premalatha K and Shankar K 2008 Synthesis 23 3787; (d) Bhosale R S, Sarda S R, Jadhav W N, Bhusare S R, Ardhapure S S and Pawar R P 2005 Tetrahedron Lett. 46 7183; (e) More S V, Sastry M N V, Wang C and Yao C F 2005 Tetrahedron Lett. 46 6345

14. (a) Zemin W and Nicholas J E 2001 Tetrahedron Lett. 42 8115; (b) Orazio A A, Lucia D C, Paolino F, Fabio M and Stefania S 2003 Synlett. 8 1183; (c) Sanjay K S, Priya G, Srinivas D and Bijoy K 2003 Synlett. 14 2147; 
(d) More S V, Sastry M N V and Yao C F 2006 Green Chem. 891

15. (a) Raw S A, Wilfred C D and Taylor R J K 2003 Chem. Commun. 18 2286; (b) Kim S Y, Park K H and Chung Y K 2005 Chem. Commun. 101321

16. (a) Das B, Venkateswarlu K, Suneel K and Majhi A 2007 Tetrahedron Lett. 48 5371; (b) Madhav B, Murthy S N, Reddy V P, Rao K R and Nageshwar Y V D 2009 Tetrahedron Lett. 506025

17. Cho C S, Ren W X and Shim S C 2007 Tetrahedron Lett. 484665

18. Antoniotti S and Dunach E 2002 Tetrahedron Lett. 43 3971
19. Anil Kumar M, Stephen Babu M F, Srinivasulu K, Kiran Y B and Suresh Reddy C 2007 J Mol. Catal. A Chem. 265268

20. (a) Bandgar B P, Bettigeri S V and Phopse J 2004 Org. Lett. 6 2105; (b) Bandgar B P, Bandgar S B, Korbad B L and Sawant S S 2007 Tetrahedron Lett. 48 1287; (c) Bandgar B P, Korbad B L, Patil S A, Bandgar S B, Chavan H V and Hote B S 2008 Aust. J. Chem. 61 700; (d) Bandgar B P, Patil S A, Korbad B L, Bandgar S B and Hote B S 2008 Aust. J. Chem. 61 552; (e) Bandgar B P, More P E, Kamble V T and Totre J V 2007 Arkivoc 48 1287; (f) Bandgar B P, Patil A V and Kamble V T 2007 Arkivoc 16252 